\title{
Cross-cultural adaptation and validation of the European Heart Failure Self-care Behavior Scale for Brazilian Portuguese
}

\author{
Maria Karolina Feijó ${ }^{1}$ \\ Christiane Wahast Ávila ${ }^{1}$ \\ Emiliane Nogueira de Souza² \\ Tiny Jaarsma ${ }^{3}$ \\ Eneida Rejane Rabelo ${ }^{4}$
}

Objective: To adapt and validate a Brazilian Portuguese version of the European Heart Failure Self-Care Behavior Scale. Methods: The cross-cultural adaptation (translation, synthesis, back-translation, expert committee review, and pretesting) and validation (assessment of face validity, content validity, and internal consistency reliability) were carried out in accordance with the literature. The European Heart Failure Self-Care Behavior Scale assesses key components of self-care: recognition of the signs and symptoms of decompensated heart failure (HF) and decision-making when these signs and symptoms arise. It comprises 12 items (range 12-60, where lower scores indicate better self-care). Results: The sample comprised $124 \mathrm{HF}$ patients with a mean age of $62.3 \pm 12$ years. The Cronbach's Alpha internal consistency was 0.70 and the intraclass correlation coefficient for reproducibility was 0.87 . Conclusion: Face and content validity, internal consistency and reproducibility have lended validity and reliability for the use of the instrument in Brazil.

Descriptors: Heart Failure; Self-care, Nursing Education; Validation Studies.

\footnotetext{
1 Master's Students, Escola de Enfermagem, Universidade Federal do Rio Grande do Sul, Brazil.

2 Doctoral student, Assistant Professor, Universidade Federal de Ciências da Saúde de Porto Alegre, Brazil.

3 PhD, Professor, Department of Social and Welfare Studies, Faculty of Health Sciences, Linköpings Universitet, Sweden.

${ }^{4} \mathrm{PhD}$, Adjunct Professor, Escola de Enfermagem, Universidade Federal do Rio Grande do Sul, Brazil.
} 


\title{
Adaptação transcultural e validação da European Heart Failure Self- care Behavior Scale para o português do Brasil
}

Objetivo: adaptar e validar a European Heart Failure Self-Care Behavior Scale para uso na língua portuguesa do Brasil. Métodos: o processo de adaptação cultural (tradução, síntese, retrotradução, revisão por comitê de especialistas e pré-teste) e validação (validade de face, de conteúdo e fidedignidade) foi realizado de acordo com a literatura. A European Heart Failure Self-Care Behavior Scale avalia os componentes-chave para o autocuidado: reconhecimento dos sinais e sintomas de descompensação da insuficiência cardíaca (IC) e a tomada de decisão na ocorrência desses sintomas. É composta por 12 questões (variando de 12-60, baixos escores indicam melhor autocuidado). Resultados: foram incluídos 124 pacientes com IC com idade de $62,3 \pm 12$ anos. A consistência interna das questões apresentou um alfa de Cronbach de 0,70 e a reprodutibilidade avaliada pelo coeficiente de correlação intraclasse foi de 0,87 . Conclusão: a validade de face, de conteúdo, a consistência interna e a reprodutibilidade conferiram validade e fidedignidade ao instrumento para uso no Brasil.

Descritores: Insuficiência Cardíaca; Autocuidado; Educação em Enfermagem; Estudos de Validação.

\section{Adaptación transcultural y validación de la European Heart Failure Self-care Behavior Scale para el Portugués de Brasil}

\begin{abstract}
Objetivo: Adaptar y validar European Heart Failure Self-Care Behavior Scale para uso en lengua portuguesa de Brasil. Métodos: El proceso de adaptación cultural (traducción, síntesis, retro traducción, revisión por comité de expertos y pré test), validación (validez de facie, de contenido y confiabilidad) fue realizado según la literatura. La European Heart Failure Self-Care Behavior Scale evalúa los componentes-clave para el auto cuidado: reconocimiento de señales y síntomas de descompensación de insuficiencia cardiaca (IC) y la decisión cuando ocurren dichos síntomas. Se compone de 12 cuestiones (que van desde 12-60, en donde las puntuaciones bajas indican peor autocuidado). Resultados: Fueron inclusos 124 pacientes con IC, con edad entre 62,3 \pm 12 años. La consistencia interna de las cuestiones presentó un Alfa de Cronbach de 0,70 y la reproducibilidad evaluada por el coeficiente de correlación. Conclusión: La validad de fase, de contenido, la consistencia interna y la reproducibilidad concedieron validad y confiabilidad al instrumento para uso en Brasil.
\end{abstract}

Descriptores: Insuficiencia Cardíaca; Autocuidado; Educación en Enfermería; Estudios de Validación.

\section{Introduction}

Recent studies have emphasized the importance of systematic education on the disease and selfcare for patients with heart failure ${ }^{(1-2)}$. The objectives of this process are to teach, strengthen, improve and constantly evaluate the abilities of patients to manage their self-care ${ }^{(1)}$. Systematic disease education contributes to the prevention of factors that might precipitate decompensation, thus reducing the number of readmissions ${ }^{(2)}$. However, information and guidance dispensed to patients in settings such as hospitals, heart failure clinics, and their own homes are not always evaluated with regard to the effectiveness of implementation ${ }^{(3)}$.

In the context of heart failure, self-care can be defined as adherence to medication, lifestyle recommendations (diet and physical exercise), and disease management 
at the earliest signs of decompensation ${ }^{(3)}$. While several questionnaires are available for assessment of self-care and disease knowledge, there are few studies suggesting brief and practical tools targeted to heart failure patients ${ }^{(3-5)}$.

In the scope of heart failure, self-care has been a focus of interest for the development of tools that could assess patient behaviors. The first such instrument, originally called the Self-management of Heart Failure Instrument, was developed by United States nurse researchers and was designed to measure patient's ability to manage their disease. Since its first publication, the instrument has been widely adapted ${ }^{(6)}$.

In Europe, a group of researchers developed and validated a scale called the European Heart Failure Selfcare Behavior Scale (EHFSCBS), which consists of 12 questions pertaining to self-care, including daily selfweighing, fluid and salt restriction, physical activity, and the support of health professionals when there are signs of decompensation. Development of the instrument was based on the theoretical framework of Orem's theory of self-care ${ }^{(7)}$. The first version of the scale was developed in Dutch and translated into English and Swedish. The 20 items of the original instrument were reassessed, and those with lower scored were excluded. The final, 12-item version of the instrument, developed in English, was retranslated into Swedish and Dutch. The same methods were then adopted for its adaptation into other languages(3). Face and concurrent validity were established and the internal consistency of the scale was tested. This scale has been validated across a variety of populations and cultures, and has been used in the assessment of over 2590 patients $^{(8-10)}$.

Currently, two validated, specific instruments are available for assessment of self-care in heart failure patients: the Self-care Heart Failure Index ${ }^{(6)}$ and the European Heart Failure Self-care Behavior Scale(3). Both have been subject to rigorous psychometric testing, but they are designed to assess different aspects of self-care behavior. Differences in the information on self-care behavior provided by the two scales allow professionals to choose the instrument best suited to the needs of their patients, to the health care providers involved and to the health care setting(11).

Our decision to validate the EHFSCBS for use in the Brazilian population was due to the aspects assessed by the original instrument, the small number of questions and the highly miscegenated nature of the Brazilian population, which would replicate the various countries in which the instrument has already been validated (the EHFScBS is currently available in 14 languages).
Furthermore, the scale assesses the two key behaviors of self-care in heart failure recognition of the signs and symptoms of decompensation and decision-making when these signs and symptoms arise providing guidance to care teams on strategies for patient stabilization ${ }^{(3)}$. The EHFScBS was recently used in a study of patients with heart failure, monitored on an outpatient basis to identify the determinants of self-care. Analysis of EHFScBS scores showed that individual resources used in the maintenance of self-care can be targets for constant improvement ${ }^{(12)}$. Thus, an educational approach to selfcare, coupled with instruments for assessment of this behavior, can be used to identify which determinants are at risk and require intensive or unique management.

As improvement or stability of the health condition of patients with heart failure is associated with selfcare, it is paramount that self-care interventions be assessed continuously with the use of validated, reliable instruments that-perhaps above all other factors-can be replicated in clinical practice ${ }^{(13)}$.

Whereas the assessment of knowledge on self-care practices is an important tool to guide the team in the follow-up and outcome of patients, the lack of easily applicable scales validated for use in Brazil prompted us to conduct this study. The results of this research could help health professionals strengthen the guidelines and strategies that improve the abilities of patients and their caregivers with respect to daily self-care practices.

\section{Objective}

The objective of this study is to adapt and validate the $E H F S C B S$ in a sample of Brazilian heart failure patients receiving outpatient follow-up at a public university hospital clinic.

\section{Methods}

\section{Study design}

Methodological studies are defined as investigations on methods for data organization and analysis designed to assess and validate research instruments and techniques(14). This study was carried out at the specialist outpatient heart failure clinic of a university hospital in South of Brazil. Data were assed from March through July 2009.

\section{Instrument}

The EHFSCBS scale validated in this study consists of 12 questions within a single domain related to self- 
care behavior. The responses for each item range from 1, "I completely agree", to 5, "I don't agree at all', on a five-point Likert-type scale. The total score is obtained by adding all of the answers and can range from 12 to 60. Lower values are indicative of better self-care. The items concern various self-care behaviors of patients with heart failure, such as daily weighing (item 1 ), rest (items 2 and 7), contacting a health care provider (items 3, 4, 5 and 8), fluid restriction (item 6), diet (item 9), medication adherence (item 10), annual flu vaccinations (item 11) and exercise (item 12) ${ }^{(3)}$.

\section{Cross-cultural adaptation}

The theoretical framework for cross-cultural adaptation used in this study is one of the most extensively described proposals for instrument adaptation, first advocated by French researchers in the early $1990 \mathrm{~s}^{(15)}$ This proposal has been revised, and its latest update was published in 2007 . The sequence of steps was as follows: translation, synthesis, backtranslation, expert committee review, pretesting, and validation of psychometric properties ${ }^{(16)}$. Before the adaptation process, permission was obtained from the authors of the original instrument to translate and validate it into Brazilian Portuguese.

Because this instrument was originally authored in a different language (English), translation by two experts in the original (source) language was required. Translator 1 should be aware of the concepts being examined in the questionnaire being translated. Their adaptations are intended to provide equivalency from a more clinical perspective, and may produce a translation that provides a more reliable equivalence from a measurement perspective. Translator 2 should be naïve to the concepts being quantified, and, preferably, should have no medical or clinical background. This translator is more likely to detect differences in meaning between the source text and first translation, will be less influenced by academic objectives, and will provide a translation that reflects the language used by the target population, often highlighting ambiguous meaning in the original questionnaire. The two versions were compared and discussed until a consensus could be reached between the translators. After the preliminary version of the instrument had been drafted, a synthesis translation was compiled with the joint participation of both translators and the investigator, along with the aid of the original document; the result was the final instrument. The back-translation stage involved translating the target instrument back into the source language. Two back-translations were produced by two persons with the source language as their mother tongue. The two translators should be neither aware nor informed of the concepts explored, and should preferably have no medical background. The main reasons are to avoid information bias and to elicit unexpected meanings of the items in the translated questionnaire, thus increasing the likelihood of "highlighting imperfections". The purpose of this stage was to improve the final translation, thereby identifying possible misinterpretations, failures of cross-cultural and contextual adaptation, and ambiguities in the source version. This version was sent to the author of the instrument, who approved the final draft(16).

A committee of experts composed of 12 professionals (three physicians, two dietitians, six postgraduate nurses working in the heart failure setting, and one language professional) evaluated the Portuguese version of the summary, aiming at consensus, agreement and improvement of the instrument. The semantic, idiomatic, experiential, and conceptual equivalences of the instrument were thereby improved. The final version was defined and pretested. After the final version had been approved, pretesting was conducted on a sample of 30 individuals of the target population of the instrument. Questions that had a misunderstanding rate of $20 \%$ or higher were reviewed(16). Approximately 10 minutes were required to administer the instrument to the patients.

\section{Psychometric properties}

Content validity was assessed by the expert committee, with analysis of the relevance of each item of the instrument. Face validity measured the comprehension and acceptance of items by the researchers and patients of the pretest sample(14-16).

The reliability of the instrument was assessed by internal consistency (Cronbach's alpha) and reproducibility (pre- and post-test). Patients who took part in the pre- and post-test stages were asked to return to the hospital after 7 to 14 days for re-administration of the instrument. Reproducibility was assessed in 24 of the 124 study subjects ${ }^{(14-16)}$.

The adapted version of the scale was named Versão brasileira da European Heart Failure Self-care Behavior scale.

\section{Sample size calculation}

The sample size was calculated as 124 patients. According to the literature, the minimum sample size 
should be at least five times larger than the number of variables being analyzed, while the most acceptable size would have a 10:1 ratio(17). According to the theoretical framework adopted for this study(16), the 30-patient pretest group did not comprise the total sample for validation. For test/retest reproducibility, 24 patients (of a total of 124) were required to detect a 4-point difference in total score, considering a correlation coefficient of $r=0.8$, a standard deviation of $9, a=0.05$, and a statistical power of $90 \%$.

\section{Study Logistics}

The instrument was applied to patients of both genders, aged 18 years or older, who had been diagnosed with heart failure (criteria similar to the inclusion criteria used for development of the original scale) $)^{(3)}$. This study was approved by the Ethics Committee of the parent institution under opinion number 08-622. Patients who had cognitive deficits that might jeopardize completion of the instrument were excluded from the sample. All patients being followed at the heart failure clinic had their cognitive status previously assessed with the MiniMental Status Exam. Patients with scores of 23 or lower were classified as having a cognitive deficit and were excluded from the study ${ }^{(18)}$.

The scale was administered by nursing researchers in a private room. A questionnaire designed to collect clinical and demographic data was also administered.

\section{Statistical analyses}

Statistical analyses were performed using the Statistical Package for the Social Sciences 17.0. Continuous variables were expressed as mean \pm standard deviation or median and interquartile range. Categorical variables were expressed as absolute and relative frequencies ( $\mathrm{n}$ and \%). The Cronbach's Alpha was used for analysis of internal consistency. Intraclass correlation coefficients were used to verify the pre- and post-test reproducibility of the instrument ${ }^{(19)}$.

\section{Results}

\section{Subjects}

The scale was administered to a sample of 124 patients with a mean age of $62.3 \pm 12$ years. Most patients were male, and $50 \%$ had up to 5 years of formal education. Other characteristics are shown in Table 1.

Table 1 - Demographic and clinical characteristics of patients with heart failure. Porto Alegre, RS, Brazil, 2009

\begin{tabular}{lc}
\hline \multicolumn{1}{c}{ Characteristics } & $\mathbf{n}=\mathbf{1 2 4}$ \\
\hline${\text { Age }(\text { years })^{*}}$ Gender (male) ${ }^{\dagger}$ & $62.3 \pm 12$ \\
Years of education $^{\ddagger}$ & $83(67)$ \\
Left ventricular ejection fraction* $^{*}$ & $5(3-5)$ \\
Medication $^{\dagger}$ & $33,6 \pm 10$ \\
Diuretics & \\
Beta blocker & $107(86)$ \\
ACEi / ARB & \\
Digoxin & $102(82)$ \\
Time since heart failure diagnosis (years) & $91(73)$ \\
\hline
\end{tabular}

Variables expressed as: * mean \pm standard deviation; $+\mathrm{n}(\%)$ categorical variables; $\neq$ median and interquartile range (25th and 75th percentiles). $\S A n g i o t e n s i n$ converting enzyme inhibitors or angiotensin receptor blockers.

\section{Cross-cultural adaptation}

During pretesting, some patients had difficulty understanding the Likert-type scale anchored at "I completely agree" then established that the questions should be adapted, as the following example shows: 'I completely agree', 'I would nearly always agree', 'I would sometimes agree', 'I would hardly ever agree' and 'I don't agree at all'. The adaptations consisted of changing the instrument scale, so as to improve patient understanding and reduce subjectivity during administration.

Questions concerning signs of heart failure decompensation (3- If my shortness of breath increases, I contact my doctor or nurse 4- If my feet or legs become more swollen than usual, I contact my doctor or nurse. 5 - If I gain $2 \mathrm{~kg}$ in 1 week, I contact my doctor or nurse. 8- If I experience increased fatigue, I contact my doctor or nurse). An additional alternative was appended to these questions, as most patients in the sample were treated within the framework of the Unified Health System and did not have a single attending physician or nurse. Thus, the questions were changed from "If I gain $2 \mathrm{~kg}$ in a week, I contact my doctor or nurse (or I seek help in some health care facility)." 


\begin{tabular}{|c|c|c|c|c|c|c|c|c|c|}
\hline \multicolumn{5}{|c|}{ Original Version of EHFScBS } & \multicolumn{5}{|c|}{ Adapted Version of EHFScBS } \\
\hline $\begin{array}{l}\text { 1- I completely } \\
\text { agree }\end{array}$ & 2 & 3 & 4 & $\begin{array}{l}\text { 5- I don't agree } \\
\text { at all }\end{array}$ & $\begin{array}{l}\text { 1-Concordo } \\
\text { plenamente }\end{array}$ & $\begin{array}{l}\text { 2- Quase sempre } \\
\text { concordo }\end{array}$ & $\begin{array}{l}\text { 3- Ás vezes } \\
\text { concordo }\end{array}$ & $\begin{array}{l}\text { 4- Quase nunca } \\
\text { concordo }\end{array}$ & $\begin{array}{l}\text { 5- Discordo } \\
\text { plenamente }\end{array}$ \\
\hline \multicolumn{5}{|c|}{ 1. I weigh myself every day. } & \multicolumn{5}{|c|}{ 1. Eu me peso todos os dias. } \\
\hline \multicolumn{5}{|c|}{ 2. If I get short of breath, I take it easy. } & \multicolumn{5}{|c|}{ 2. Se sinto falta de ar, repouso. } \\
\hline \multicolumn{5}{|c|}{$\begin{array}{l}\text { 3. If my shortness of breath increases, I contact my } \\
\text { doctor or nurse. }\end{array}$} & \multicolumn{5}{|c|}{$\begin{array}{l}\text { 3. Se minha falta de ar aumenta, entro em contato com meu médico ou com a enfermeira } \\
\text { (ou algum serviço de saúde) }\end{array}$} \\
\hline \multicolumn{5}{|c|}{$\begin{array}{l}\text { 4. If my feet or legs become more swollen than usual, I } \\
\text { contact my doctor or nurse. }\end{array}$} & \multicolumn{5}{|c|}{$\begin{array}{l}\text { 4. Se meus pés ou pernas tornarem-se mais inchados do que de costume, entro em } \\
\text { contato com meu médico ou com a enfermeira (ou algum serviço de saúde) }\end{array}$} \\
\hline \multicolumn{5}{|c|}{ 5. If I gain 2 kg in 1 week, I contact my doctor or nurse. } & \multicolumn{5}{|c|}{$\begin{array}{l}\text { 5. Se eu ganhar } 2 \mathrm{Kg} \text { em } 1 \text { semana, entro em contato com meu médico ou com a } \\
\text { enfermeira (ou algum serviço de saúde) }\end{array}$} \\
\hline \multicolumn{5}{|c|}{$\begin{array}{l}\text { 6. I limit the amount of fluids I drink (not more } \\
\text { than } 1.5-2 \mathrm{l} / \mathrm{day} \text { ). }\end{array}$} & \multicolumn{5}{|c|}{ 6. Limito a quantidade de líquidos que bebo (não mais do que 1,5 a 2 I por dia). } \\
\hline \multicolumn{5}{|c|}{ 7. I take a rest during the day. } & \multicolumn{5}{|c|}{ 7. Descanso durante o dia. } \\
\hline \multicolumn{5}{|c|}{$\begin{array}{l}\text { 8. If I experience increased fatigue, I contact my doctor } \\
\text { or nurse. }\end{array}$} & \multicolumn{5}{|c|}{$\begin{array}{l}\text { 8. Se meu cansaço aumenta, Se meu cansaço aumenta, entro em contato com meu } \\
\text { médico ou com a enfermeira (ou algum serviço de saúde) }\end{array}$} \\
\hline \multicolumn{5}{|c|}{ 9. I eat a low salt diet. } & \multicolumn{5}{|c|}{ 9. Ingiro uma dieta com pouco sal. } \\
\hline \multicolumn{5}{|c|}{ 10. I take my medication as prescribed. } & \multicolumn{5}{|c|}{ 10. Tomo meu medicamento de acordo com a prescrição. } \\
\hline \multicolumn{5}{|c|}{ 11. I get a flu shot every year. } & \multicolumn{5}{|c|}{ 11. Tomo a vacina contra a gripe todos os anos. } \\
\hline \multicolumn{5}{|c|}{ 12. I exercise regularly. } & \multicolumn{5}{|c|}{ 12. Faço exercícios regularmente. } \\
\hline
\end{tabular}

EHFScBS score: original study and validation of the Brazilian version of the European Heart Failure Self-care Behavior Scale.

Figure 1- Original and adapted version of items of the European Heart Failure Self-care Behavior Scale (EHFScBS). Porto Alegre, RS, Brazil, 2009

The mean scores of the instruments are shown in administered at a heart failure clinic. In this study, the Table 2. As with the original instrument ${ }^{(3)}$, the scale was total score was $24.7 \pm 8.5$.

Table 2 - Scores of the original self-care scale and those of the Brazilian version of the European Heart Failure Selfcare Behavior Scale sample. Porto Alegre, RS, Brazil, 2009

\begin{tabular}{|c|c|c|}
\hline Item & Original study $(n=442)$ & Adapted version $(n=124)$ \\
\hline 1. Eu me peso todos os dias & $3.1 \pm 1.7$ & $3.6 \pm 1.5$ \\
\hline 2. Se sinto falta de ar, repouso & $1.5 \pm 1.1$ & $1.5 \pm 1.2$ \\
\hline $\begin{array}{l}\text { 3. Se minha falta de ar aumenta, entro em contato com meu médico ou com a } \\
\text { enfermeira (ou algum serviço de saúde) }\end{array}$ & $2.4 \pm 1.7$ & $2.0 \pm 1.7$ \\
\hline $\begin{array}{l}\text { 4. Se meus pés ou pernas tornarem-se mais inchados do que de costume, entro em } \\
\text { contato com meu médico ou com a enfermeira (ou algum serviço de saúde) }\end{array}$ & $2.3 \pm 1.7$ & $2.3 \pm 1.8$ \\
\hline $\begin{array}{l}\text { 5. Se eu ganhar } 2 \mathrm{~kg} \text { em } 1 \text { semana, entro em contato com meu médico ou com a } \\
\text { enfermeira (ou algum serviço de saúde) }\end{array}$ & $2.6 \pm 1.8$ & $2.8 \pm 1.9$ \\
\hline 6. Limito a quantidade de líquidos que bebo (não mais do que 1,5 a 2 I por dia) & $2.3 \pm 1.6$ & $1.7 \pm 1.2$ \\
\hline 7. Descanso durante o dia & $1.8 \pm 1.4$ & $1.4 \pm 1.0$ \\
\hline $\begin{array}{l}\text { 8. Se meu cansaço aumenta, entro em contato com meu médico ou com a } \\
\text { enfermeira (ou algum serviço de saúde) }\end{array}$ & $2.8 \pm 1.7$ & $2.4 \pm 1.8$ \\
\hline 9. Ingiro uma dieta com pouco sal & $2.2 \pm 1.4$ & $1.3 \pm 0.8$ \\
\hline 10. Tomo meu medicamento de acordo com a prescrição & $1.2 \pm 0.9$ & $1.0 \pm 0.3$ \\
\hline 11. Tomo a vacina contra a gripe todos os anos & $2.4 \pm 1.9$ & $2.7 \pm 1.9$ \\
\hline 12. Faço exercícios regularmente & $3.1 \pm 1.6$ & $3.2 \pm 1.8$ \\
\hline Total score* & $29.6 \pm 9$ & $24.7 \pm 8.5$ \\
\hline
\end{tabular}

* Variable expressed as mean \pm standard deviation.

\section{Reliability}

\section{Internal consistency}

The Cronbach's alpha reliability coefficient ranged from .61 to .70. In Table 3 below, the coefficients for total, item-total correlation, and after deletion of each item are shown. 
Table 3 - Analysis of the reliability of the European Heart Failure Self-care Behavior Scale adapted version for patients with heart failure. Porto Alegre, RS, Brazil, 2009

\begin{tabular}{|c|c|c|}
\hline Item (Cronbach's alpha $=0.70)$ & $\begin{array}{l}\text { Corrected item-total } \\
\text { correlation }\end{array}$ & $\begin{array}{c}\text { Cronbach's alpha if } \\
\text { item deleted }\end{array}$ \\
\hline 1. Eu me peso todos os dias & 0.13 & 0.70 \\
\hline 2. Se sinto falta de ar, repouso & 0.21 & 0.67 \\
\hline $\begin{array}{l}\text { 3. Se minha falta de ar aumenta, entro em contato com meu médico ou com a enfermeira (ou } \\
\text { algum serviço de saúde) }\end{array}$ & 0.58 & 0.61 \\
\hline $\begin{array}{l}\text { 4. Se meus pés ou pernas tornarem-se mais inchados do que de costume, entro em contato } \\
\text { com meu médico ou com a enfermeira (ou algum serviço de saúde) }\end{array}$ & 0.48 & 0.62 \\
\hline $\begin{array}{l}\text { 5. Se eu ganhar } 2 \mathrm{~kg} \text { em } 1 \text { semana, entro em contato com meu médico ou com a enfermeira (ou } \\
\text { algum serviço de saúde) }\end{array}$ & 0.42 & 0.64 \\
\hline 6. Limito a quantidade de líquidos que bebo (não mais do que 1,5 a 2 I por dia) & 0.31 & 0.66 \\
\hline 7. Descanso durante o dia & 0.18 & 0.67 \\
\hline $\begin{array}{l}\text { 8. Se meu cansaço aumenta, entro em contato com meu médico ou com a enfermeira (ou } \\
\text { algum serviço de saúde) }\end{array}$ & 0.55 & 0.61 \\
\hline 9. Ingiro uma dieta com pouco sal & 0.27 & 0.67 \\
\hline 10. Tomo meu medicamento de acordo com a prescrição & 0.20 & 0.68 \\
\hline 11. Tomo a vacina contra a gripe todos os anos & 0.26 & 0.67 \\
\hline 12. Faço exercícios regularmente & 0.23 & 0.67 \\
\hline
\end{tabular}

\section{Pre-and post-test reproducibility}

For assessment of reproducibility, data from 24 patients who completed pre- and post-testing were analyzed. The intraclass correlation coefficient was 0.87 .

\section{Discussion}

This study aimed to translate, adapt and validate the $E H F S C B S$ instrument for the Brazilian population. A pilot adaptation of the instrument was pretested in a sample of Brazilian patients diagnosed with heart failure and being followed at the specialized outpatient clinic of a university hospital.

Two adaptations were carried out during pretesting. The first consisted of inserting a sentence that corresponded to the answers for items 2, 3 and 4, so as to reduce the subjectivity of patient responses. The second adjustment was made to items concerning the recognition of signs of decompensation and the seeking of medical attention. Because this study was conducted in a public hospital, the possibility that patients might seek care at a health care facility in case of decompensation was added to each item.

A new version of this instrument was recently developed by the same author of the original scale. Statements such as "If I feel shortness of breath, I rest", "I rest during the day" and "I take the flu shot every year" were removed. The authors inferred that patients perform these actions as a result of disease progression or worsening symptoms, which does not indicate a better ability to manage self-care. In addition, they decided that annual vaccination against influenza is not a heart failure-specific care measure ${ }^{(20)}$. In the version of the scale validated for use in Brazil, the scores found for these items were similar to those of the original study, and no difficulties were found in subsequent administration of the instrument. While the questions concerning rest do not reveal a better ability for selfcare, we consider vaccination against the flu virus to be an important measure. During administration of the scale, we identified that patients were unaware of the importance of that measure, thereby reinforcing the importance of the guidelines provided during patient encounters ${ }^{(20)}$.

The internal consistency of the adapted version of the scale was determined by means of Cronbach's alpha. In a sample of 124 patients, the alpha was 0.70 . Some authors suggest that the internal consistency of items be classified as follows: values $\geq 0.9$ are considered excellent, $\geq 0.8$ are considered good, $\geq 0.7$ are acceptable, $\geq 0.6$ are questionable, $\geq 0.5$ are poor, and $\leq 0.5$ are considered unacceptable. However, there is actually no lower limit to the coefficient ${ }^{(16)}$. In some research settings, such as the social sciences, a Cronbach's alpha of 0.6 is considered acceptable as long as results are interpreted cautiously ${ }^{(21)}$. In a metaanalysis, Cronbach's alpha values ranged from 0.70 to 0.82 ; however, there was no relationship between alpha size and the studied characteristics(22). Although the Cronbach's alpha coefficient found in this study was lower than that of the original study $(0.81)$, it is within the acceptable range.

In the present study, the reproducibility of the instrument was verified in 24 patients by means of pre- 
and post-testing. The intraclass correlation coefficient was chosen, as the kappa statistic requires that all scores occur at least once. As most responses gave a score of 1,3 , or 5 , the kappa coefficient could not be used. The intraclass correlation coefficient was 0.87 (adequate). Validation studies of the EHFSCBS conducted in Europe reported similar results ${ }^{(23-25)}$. A Japanese study conducted to validate the EHFSCBS in the outpatient setting found reproducibility values of 0.33 to 0.87 , as measured by the kappa coefficient ${ }^{(24)}$. Therefore, this reproducibility coefficient obtained in two non-European countries is indicative of instrument adequacy.

When analyzed, the score of the scale validated for Portuguese was higher than that found in the original study for patients in a specialized outpatient clinic who received nursing guidance before self-administering the instrument ${ }^{(3)}$. Results were lower in a study conducted in Japan, with scores that evinced a decreased ability for self-care when compared to that of other populations; yet, the patients received guidance in a setting very similar to that of the other studies(24).

Self-care is still the subject of investigation in a variety of settings, mainly because it is recognized as a key component for patients to enjoy the benefits of treatment. However, the practical application of self-care by patients and their caregivers is an ongoing exercise of persistence, and its results can be observed in the medium and long term ${ }^{(6)}$.

The development of scales that allow teams to assess these parameters becomes essential in this context, and should be followed by validation for different languages. In this way, reviews for the update and improvement of previously validated instruments have become necessary for clinical practice ${ }^{(3,26)}$.

Because no instruments designed to assess selfcare in patients with heart failure have ever been validated for Brazilian populations, criterion validity could not be established, as this would have required the use of a gold-standard instrument. We believe this was the main limitation of this study.

The results of this study show that the instrument tested herein is valid and reproducible for assessment of the self-care behavior of Brazilian heart failure patient. The instrument proves to be a useful, fast and userfriendly tool in any healthcare setting.

The validation of EHFSCBS may allow its administration in various practice scenarios (heart failure clinics, home, primary care facilities, and phone monitoring). This instrument will provide treating nurses and physicians with objective self- care behavior parameters, particularly regarding patient acknowledgement of the benefits of treatment adherence.

\section{Conclusions}

The EHFSCBS instrument was successfully adapted and validated for Brazilian populations. It has proved to be an important tool for assessment of self-care in heart failure patients and, consequently, for assessment of the effectiveness of actions implemented by multidisciplinary heart failure care teams.

\section{References}

1. Rabelo ER, Aliti GB, Domingues FB, Ruschel KB, Brun $A O$. What to teach to patients with heart failure and why: the role of nurses in heart failure clinics. Rev. Latino-Am. Enfermagem. 2007;15(1):165-70.

2. ESC Guidelines for the diagnosis and treatment of acute and chronic heart failure 2008: the Task Force for the diagnosis and treatment of acute and chronic heart failure 2008 of the European Society of Cardiology. Developed in collaboration with the Heart Failure Association of the ESC (HFA) and endorsed by the European Society of Intensive Care Medicine (ESICM). Eur J Heart Fail. 2008;10:933-89.

3. Jaarsma T, Stromberg A, Martensson J, Dracup K. Development and testing of the European Heart Failure Self- care Behaviour Scale. Eur J Heart Fail. 2003;5(3):363-70.

4. Conelly CE. An empirical study of a model of self- care in chronic illness. Clin Nurse Spec. 1993;7(5):247-53.

5. Riegel B, Carlson B, Glaser D. Development and testing of a clinical tool measuring self-management of heart failure. Heart Lung. 2000;29(1):4-15.

6. Riegel B, Carlson B, Moser DK, Sebern M, Hicks FD, Roland V. Psychometric Testing of the Self-care of Heart Failure Index. J Card Fail. 2004 10: 350-60.

7. Orem DE.Nursing: concepts of practice, 5th. ed. St. Louis: Mosby; 1995. 303 p.

8. Shuldham C, Theaker C, Jaarsma T, Cowie MR. Evaluation of the European Heart Failure Self-care Behaviour Scale in a United Kingdom population. J Adv Nurs. 2007;60(1):87-95.

9. Kato N, Ito N, Kinugawa K, Kazuma K. Validity and reliability of the Japanese version of the European Heart Failure Self-Care Behavior Scale. Eur J Cardiovasc Nurs. 2008;7(4):284-9.

10. Gonzalez B, Lupon J, Parajon T, Urrutia A, Herreros $J$, Valle V. Use of the European Heart Failure Self-care 
Behavior Scale (EHFScBS) in a heart failure unit in Spain. Rev Esp Cardiol. 2006;59(2):166-70.

11. Yu DS, Lee DT, Thompson DR, Woo J, Leung E. Assessing self-care behaviour of heart failure patients: cross-cultural adaptation of two heart failure self-care instruments. Hong Kong Med J. 2010;16(3):13-6.

12. Peters-Klimm $F$, Freund $T$, Kunz C, Laux G, Frankenstein $L$, Müller-Tasch $T$, et al. Determinants of heart failure self-care behaviour in community-based patients: a cross-sectional study. Eur J Cardiovasc Nurs. ahead of print Epub 13Apr 2012.

13. Haasenritter J, Panfil EM. Assessment instruments for the measurement of the health-related self-care of patients with heart failure. Pflege. 2008;21(4):235-51.

14. Wood GL, Haber J. Desenhos não-experimentais. In: Wood GL, Haber J. Pesquisa em Enfermagem: métodos, avaliação crítica e utilização. Rio de Janeiro (RJ): Guanabara Koogan; 2001. p. 110-21.

15. Guillemin F, Bombardier C, Beaton D. Cross-cultural adaptation of health-related quality of life measures: literature review and proposed guidelines. J Clin Epidemiol. 1993;46(12):1417-32.

16. Beaton D, Bombardier C, Guillemin F, Ferraz MB. Recommendations for the Cross- Cultural Adaptation of the DASH \& Quick DASH Outcome Measures; 2007.

17. Hair JF, Anderson RE, Tatham RL, Black WC. Análise fatorial. In: Hair JF, Anderson RE, Tatham RL, Black WC. Análise multivariada de dados. Porto Alegre (RS): Bookman; 2005. p. 89-127.

18. Folstein MF, Folstein SE, McHugh PR. Mini-mental state: a practical method for grading the cognitive state of patients for the clinician. J Psychiatr Res. 1975;12(3):189-98.

19. Beaton DE, Bombardier C, Guillemin F, Ferraz MB. Guidelines for the process of cross-cultural adaptation of self-report measures. Spine. 2000; 25(24):3186-91.

20. Jaarsma T, Arestedt KF, Martensson J, Dracup K, Stromberg A. The European Heart Failure Selfcare Behaviour Scale revised into a nine-item scale (EHFSCB-9): a reliable and valid international instrument. Eur J Heart Fail. 2009;11(1):99-105.

21. Gliem JA, Gliem RR. Calculating, interpreting, and reporting Cronbach's alpha reliability coefficient for Likert-type scales. In: Midwest Research- to- Practice Conference in Adult, Continuing, and Community Education. Columbus; 2003. p. 82-8.

22. Peterson RA. A meta-analysis of Cronbach's coefficient alpha. J Consum Res. 1994;21(2):381-91.
23. Shuldham C, Theaker C, Jaarsma T, Cowie MR. Evaluation of the European Heart Failure Self-care Behaviour Scale in a United Kingdom population. J Adv Nurs. 2007;60(1):87-95.

24. Kato N, Ito N, Kinugawa K, Kazuma K. Validity and reliability of the Japanese version of the European Heart Failure Self-Care Behavior Scale. Eur J Cardiovasc Nurs. 2008;7(4):284-9.

25. Gonzalez B, Lupon J, Parajon T, Urrutia A, Herreros J, Valle V. Use of the European Heart Failure Self-care Behavior Scale (EHFScBS) in a heart failure unit in Spain. Rev Esp Cardiol. 2006;59(2):166-70.

26. Riegel B, Lee CS, Dickson VV, Carlson B. An update on the Self-care of Heart Failure Index. J Cardiovasc Nurs. $2009 ; 24(6): 485-97$. 